\title{
ВИНИКНЕННЯ ТА ПОХОДЖЕННЯ КРИПТОВАЛЮТ, ЇХ ПОТЕНЦІАЛ ЯК ПЛАТІЖНОГО ЗАСОБУ
}

\author{
КОВРИГА Микола Миколайович - аспірант кафедри публічно-правових \\ дисциплін Київського міжнародного університету
}

DOI:10.32782/NP.2019.4.24

УДК 347.73

В представленной статье приведеньл исследования истории возникновения, происхождение, становление криптовалют. Особое внимание уделено исследованию работ изобретателей и ученьх, которье предшествовали и стали основой для будущего создания криптовалют.

В данной статье проанализированъ основные кониепиии и теоретические идеи, которьле стали базой и сущностнълм основанием для попьлтки реализачии новой концепчии, в виде создания дечентрализованной электронной денежной системъ. Системъ, которая смогла бы стать альтернативой современнъим денежнъм системам, и смогла бъ ответить на въззов и потребности общества, такие как, скорость и простота трансграничнъгх фбинансовъхх операчий, уменьшение количества (исключение) посредников, децентрализачия системь, то есть реализачия равноправия субъектов в сбере денежного обращения.

Важныл аспектом развития криптовалют есть возможность и перспектива их использования в качестве средства платежа. Поэтому в приведенном исследовании проведен анализ их основнъих преимуществ и недостатков, как средства платежа. Сделанъ въгводы о перспективах криптовалют стать составляющей мировой бинансовой системъı.

Ключевъе слова: криптовалюта, электроннъие денъги, Bitcoin, Ripple, денежная система, средство платежа.

\section{Постановка проблеми}

Криптовалюти є досить новим об'єктом прав. За трохи більше ніж 10 років існування, криптовалюти створили чимало викликів сучасній фінансовій системі, спонукали перегляд встановлених концепцій у сфері обігу активів, грошових платежів тощо. Незважаючи на стрімке збільшення популярності, криптовалюти не мають чітко визначеного правового статусу, що створює суттєві ризики у процесі використання криптовалют як засобів платежу.

Для розуміння правової природи та напрямків розвитку криптовалют, доцільно дослідити їх історію виникнення та становлення, їх переваги та недоліки.

Незважаючи на суттєвий інтерес як практичний, так і теоретичний, дане питання ще є недостатньо дослідженим.

\section{Аналіз дослідження}

Новизна, багатофункціональність, потенціал такого явища як криптовалюти, зумовили зростання наукових зацікавлень як вітчизняних, так і зарубіжних учених. Даному питанню приділяли увагу в тому числі: Е.Н. Аобачова, В.Г., Родіонова, С. Б. Вепрев, Б. Бернанк, А. Грінспен, Ф. Журавко, А. Т. Проценко, Д. Ален, М. Епіфанов, М. Абрамович, А. Колдовський, Дж. Потс, Д. С. Вахрушев, Р. Шульц та ін. Проте, незважаючи на увагу науковців, значення та перспективи розвитку криптовалют потребують подальшого дослідження та теоретичного аналізу. 


\section{Банківське та фінансове право}

\section{Формулювання цілей дослідження}

Метою статті є дослідження передумов виникнення, аналіз розвитку та становлення криптовалют, оцінка їх потенціалу як платіжного засобу.

\section{Виклад основного матеріалу}

Достеменно встановити, хто саме є засновником або винахідником криптовалют, досить складно, адже навіть найперша криптовалюта Bitcoin була створена невідомою особою або групою осіб під псевдонімом Сатоші Накамото, і офіційно так і не було з'ясовано, хто саме стоїть за цим ім'ям. Історії відомі спроби певних осіб присвоїти собі або іншим даний статус.

Так, один із розробників коду Bitcoin Джефф Гарзик (англ. Jeff Garzik) стверджував, що експерт 3 комп'ютерної безпеки Дейв Клейман (англ. Dave Kleiman), який помер у 2013 році, - це Сатоші Накамото [1].

У 2018 року брат Дейва Клеймана, Айра (англ. Ira Kleiman), подав судовий позов проти Крейга Райта з Австралії, який оголосив себе Сатоші Накамото. Айра представив суду переписку брата 3 австралійцем, яка начебто підтверджує створення Bitcoin саме Дейвом Клейманом [2].

У свою чергу, у 2016 році спеціаліст у галузі теорії обчислювальних машин і систем Крейг Стівен Райт (англ. Craig Steven Wright) оголосив, що він нібито дійсно є автором Bitcoin. Однак те, що Райт описав у своєму блозі та надав деяким журналістам як доказ авторства Bitcoin, виявилось не достатньо переконливим [3].

По сьогодні беззаперечних та достатніх доказів, які підтверджували 6 авторство Bitcoin, ніхто так і не надав.

Незважаючи на те, що першою криптовалютою вважають саме Bitcoin, його створенню передували спроби та дослідження інших вчених та винахідників.

Так, американський вчений та криптограф Девід Аі Чаум (англ. David Lee Chaum) у 1982 році придумав концепцію електронних грошей (ecash), а пізніше ним же була запропонована перша реалізація «сліпого підпису» (англ. blind signature) через алгоритм RSA (абревіатура від прізвищ Rivest,
Shamir та Adleman) [4] для переказів у системі електронних грошей [5].

У 1994 році Девід Чаум організував першу мережеву систему електронних грошей DigiCash, яка забезпечувала анонімність платежів для покупця, безпеку для продавця та мала можливість реалізації мікроплатежів [6, с. 295-296].

У 1998 році Вей Дай (англ. Wei Dai), випускник Вашингтонського університету, розробив концепцію анонімної, розподільної системи електронних грошей B-money. Така система описувала основні характеристики сучасних криптовалют, але проект так і не вийшов зі стадії концепту [7].

У тому ж 1998 році, американський дослідник у галузі інформатики, криптографії, а також в області права Нік Сабо (англ. Nick Szabo) розробив алгоритм децентралізованої цифрової валюти, яку він назвав «bit gold» [8].

Однак, дана система мала певні технологічні та сутнісні недоліки. Нік Сабо так і не вирішив проблему подвійної витрати грошей, коли власник «bit gold» міг двічі розплатитися одними і тими ж грошима, проблему контролю транзакцій, номіналу тощо. До того ж дана грошова система не була анонімною, так як засновник не бачив у цьому необхідності. Сабо, працюючи над своїм проектом до 2005 року, так і не зміг втілити його у життя [9].

На основі досвіду попередніх спроб у 2008 було розроблено першу криптовалюту - Bitcoin.

31 жовтня 2008 року особа або група осіб під псевдонімом Сатоші Накамото опублікувала в списку поштової розсилки з криптографії статтю «Біткоїн: рівноправна електронна грошова система» (англ. «Bitcoin: A Peer-to-Peer Electronic Cash System») [10][11], у даній статті було описано повністю децентралізовану систему електронної готівки.

Уже 9 січня 2009 року вийшов Bitcoin 0.1. та було реалізовано першу версію програмного забезпечення для використання Bitcoin [12].

Вперше криптовалюту було надіслано 12 січня 2009 року. Сатоші Накамото відправив 10 Bitcoin Хелу Фінні (англ. Hal Finney). Ця транзакція також відома як «блок 170» 
(за номером блоку, в якому вона була зафіксована) [9].

Перші торги криптовалютою відбувалися на платформі New Liberty Standart. Bapтість 1300 Bitcoin на той момент становила 1 долар СІІА [7].

Перший обмін криптовалюти на товар відбувся 22 травня 2010 року у Флориді, коли програміст Аасло Ханеч (англ. Laszlo Hanyecz) обміняв 10000 Bitcoin на 2 піци, вартість яких на той момент становила 24 долари США, що за курсом на кінець 2019 рік склало більше ніж 70 мільйонів доларів CIIIA [9].

Bitcoin версії 0.2.0 вийшов майже рік по тому, в грудні 2009. Це була перша версія, яка підтримувала Linux. Крім того, цей реліз вже міг використовувати кілька потоків для генерації блоків [12].

Влітку 2010 року було реалізовано абсолютно новий інструмент для торгів криптовалютами, було відкрито біржу для торгів криптовалютними активами - Mount Gox (Mt.Gox) [7].

3 часом розвиток криптовалют досяг досить суттєвих обертів, за десять років існування даної технології з'явилося майже 5000 різних криптовалют із загальною капіталізацією понад 194 мільярди доларів США (станом на кінець 2019 року) [13].

За період свого існування криптовалюти використовувались як засіб інвестування, програмний продукт, товар, актив, засіб платежу, єдиного підходу на сьогодні немає. У свою чергу, криптовалюти у своєму первинному розумінні задумувались саме як засіб платежу, свого роду альтернатива існуючим принципам та способам організації грошового обігу, тобто концепція криптовалют полягала у створенні нового, інноваційного виду грошової системи в протидію сучасним централізованим та історично сформованим грошовим системам.

Як визначає В.Д. Базилевич, грошова система - це форма організації грошового обігу, яка історично склалася в певній країні й законодавчо закріплена державою [14]. Виходячи 3 вказаного поняття, програмну мережу певної криптовалюти, наприклад Bitcoin, яка в цілому є самодостатньою платіжною системою з власною грошовою оди- ницею, на сьогодні складно назвати грошовою системою, адже все ще досить незначна кількість суб'єктів приймає криптовалюти, ïх історія використання нетривала, а визначений законодавчо врегулюваний спосіб користування криптовалютами як засобом платежу та їх правовий статус фактично незакріплений у жодній країні. I хоча певні країни, такі як Швейцарія, Японія, Німеччина спробували надати правові рекомендації з даного питання, повноцінного регулювання даної сфери на сьогодні немає.

Однак як засіб платежу криптовалюти досить активно розповсюджуються на практиці, в першу чергу через певні переваги щодо класичних сучасних систем.

Так, серед позитивних аспектів криптовалют можна визначити:

1. За допомогою криптовалют можливо проводити купівлю-продаж товарів, послуг тощо.

2. У загальному більш швидкий (в залежності від криптовалюти, в мережі Bitcoin від декількох хвилин до декількох годин, у мережі Ripple - декілька секунд), дешевий та простий спосіб здійснення транскордонних платежів. Система переказів RippleNet побудована на блокчейн технології Ripple активно тестується банками та платіжними системами (наприклад: TransferGo, MoneyGram, AxisBank, AKBANK).

3. Відносно більшості криптовалют - децентралізована система, яка не має емісійного центру, як наслідок знижений ризик контролю одним або декількома суб'єктами всієї системи, формування курсу не за суб'єктивним підходом, а за ринковим, на підставі співвідношення попиту та пропозиції.

4. Можливість переказу як досить значних сум, декілька мільйонів доларів СІІА в еквіваленті, так і мікросум, можливе ділення криптовалют на менші частини (Bitcoin можна поділити на «сатоші» - стомільйонну частку). Принцип та спосіб не відрізняються від розміру переказу.

5. Анонімність переказів. Даний критерій можливо віднести як до позитивних аспектів, так і до негативних. Анонімність переказів виключає можливість контролю третіми особами, що, з одного боку, дає біль- 


\section{Банківське та фінансове право}

шу надійність та безпеку користувачам, а 3 іншого, виключає можливість відміни операції або повернення грошей у разі помилкових транзакцій.

При цьому варто зазначити, що анонімність деяких криптовалют, таких як Bitcoin, Litecoin та ін., є дещо умовною, адже блокчейн, як правило, це технологія публічного реєстру, де всі транзакції, починаючи 3 самої першої, доступні будь-кому у вигляді даних про час та суму переказу, а також про адреси гаманців.

У свою чергу до недоліків криптовалют, як засобу платежу можна віднести:

1. Специфіка технічної складності користування. Для використання платежів криптовалютами обов'язково необхідне спеціальне комп'ютерне (інші подібні пристрої: смартфон, планшет, термінал тощо) обладнання та додаткові програмні рішення: гаманці, криптовалютні біржі тощо.

Однак варто зауважити, що криптова^юти як об'єкт є досить молодим, а вже за такий короткий період технологічні можливості використання криптовалют є досить розвиненими, і швидкість цього розвитку тільки збільшується. Постійно з'являються нові програмні продукти або навіть способи користування криптовалютами: мультивалютні картки типу Visa чи MasterCard (AdvCash, UQUID, Monaco та інші) [16], інтернет платіжні системи (WayForPay), мессенджер-боти 3 функцією гаманця криптовалют та інші. Крім того, на сьогодні людство у звичайному режимі користується безготівковими розрахунками, електронними грошима, хоча дані технології були інноваціями ще зовсім недавно.

2. На сьогодні остаточно неврегульовано правовий статус криптовалют, як наслідок існує значний ризик незахищеності користувачів у межах сучасної правової системи. «Емісія» криптовалют виявилася непідконтрольною ні законодавству, ні уряду, ні банківській системі будь-якої з країн [17].

3. Відносно незначна обізнаність суспільства 3 даним новим об'єктом, що гальмує розвиток даної технології та стимулює шахрайські та протизаконні схеми $з$ обігом криптовалют.
4. Висока волатильність криптовалют, тобто швидка зміна курсів вартості криптовалют на ринку.

5. Анонімність може бути як перевагою так і недоліком. Як вже було сказано вище, вона дає більшу надійність та безпеку користувачам, однак і обмежує можливості повернення коштів у разі помилковості операцій. Але найбільшим ризиком криптовалют, який випливає 3 анонімності, звичайно, 6 їх використання у незаконній діяльності. I хоча зі звичайними (класичними) грошима, тим паче готівковими коштами, незаконних операцій здійснюється досить багато, криптовалюти є популярним способом розрахунку в злочинній діяльності, особливо у технологічній сфері (Даркнет (англ. dark net), хакерські атаки [18] тощо).

\section{Висновки}

Незважаючи на короткий період існування, криптовалюти та пов'язані 3 ними інструменти активно розвиваються. Основна ідея створення даного інструменту полягала у пошуку альтернативи сучасним фінансовим механізмам та тій грошовій системі, яка використовується в сучасному суспільстві. При наявності досить суттєвих недоліків криптовалют, таких як висока волатильність, відсутність правового регулювання, високий ризик шахрайських та протизаконних схем, специфічність технічних аспектів їх використання, криптовалюти все більше входять у суспільний обіг та частіше використовуються як засоби платежу. Така зацікавленість продиктована необхідністю пошуку нових, більш швидких та простих способів здійснення транскордонних платежів, з відносно низькими комісіями та відсутністю великої кількості посередників (наприклад банків кореспондентів). Не останню роль у популяризації криптовалют відіграли їх криптографічний рівень захисту, децентралізована структура та анонімність.

За досить коротку історію існування криптовалюти пройшли досить суттєвий шлях як $з$ технологічної, так і з суспільної точки зору. Враховуючи той факт, що в сучасному світі періоди становлення технологій скорочуються, можна припустити, що 


\section{АНОТАЦІЯ}

У представленій статті наведено дослідження історій виникнення, походження, становлення криптовалют. Окрему увагу приділено дослідженню робіт винахідників та вчених, які передували та стали основою для майбутнъого створення криптовалют.

у даній статті проаналізовано основні концепциї та теоретичні ідё, які стали базою та сутнісною підставою для спроби реалізаиій нової концепиій, у вигляді створення дещентралізованої електронної грошової системи. Системи, яка б змогла стати альтернативою сучасним грошовим системам та могла відповісти на виклики і потреби суспільства, такі як швидкість та простота транскордонних фінансових операчій, зменшення кількосmі (виключення) посередників, децентралізаиія системи, тобто реалізаиї рівноправності суб'єктів у сфері грошового обігу.

Важливим аспектом розвитку криптовалют є можливість та перспектива їх використання як засобу платежу. Тому в наведеному досліджені проведено аналіз їх основних переваг та недоліків як засобу платежу. Зроблено висновки щодо перспектив криптовалют стати складовою світової бінансової системи.

Ключові слова: криптовалюта, електронні гроші, Bitcoin, Ripple, грошова система, засіб платежу.

досить скоро криптовалюти стануть суттевою складовою світової фінансової системи.

\section{Лiтература}

1. Джефф Гарзик вызван в суд для дачи показаний против Крейга Райта. URL: https://hashtelegraph.com/dzheff-garzik-vyzvan-v-sud-dlja-dachi-pokazanij-protiv-krejgarajta/ (дата звернення: 29.12.2019).

2. Крейг Райт. URL: https:/hashtelegraph.com/krejg-rajt/ (дата звернення: 29.12.2019).

3. Почему Крейг Райт - не Сатоси Накамото. URL: https://bits.media/pochemukreyg-rayt-ne-satosi-nakamoto/ (дата звернення: 29.12.2019).

4. RSA. URL: https://uk.wikipedia.org/ wiki/RSA (дата звернення: 29.12.2019).

5. Marcell Nimfuehr. The Amazing Story of Cryptocurrencies Before Bitcoin. URL: https://hackernoon.com/the-amazing-story-ofcryptocurrencies-before-bitcoin-fe 1b0e 55155b (дата звернення: 29.12.2019).

6. Гид по финансовой грамотности / кол. авторов. - М. : КНОРУС: ЦИПСиР, 2010. $-456 \mathrm{c}$.

7. История криптовалют и трейдинга. URL: https://magazine.decenter.org/ru/4treiding/67-istoriya-kriptovalyut-i-treidinga (дата звернення: 29.12.2019).

8. Nick Szabo. Secure Property Titles with Owner Authority. URL: https://nakamotoinstitute.org/secure-property-titles/ (дата звернення: 29.12.2019).

9. Федорова Ю.В. Криптовалюти та їх місце у фінансовій системі / Економіка і суспільство гроші, фінанси і кредит. 2018, Випуск № 15 - с. 8-9. URL: http://www. economyandsociety.in.ua/journal/15_ukr/116. pdf (дата звернення: 29.12.2019).

10. Bitcoin P2P e-cash paper. URL: https:// archive.is/20121228025845/http://article. gmane.org/gmane.comp.encryption.general/12588/ (дата звернення: 29.12.2019).

11. Satoshi Nakamoto. Bitcoin: A Peer-toPeer Electronic Cash System. bitcoin.org. 2008. URL: https://bitcoin.org/bitcoin.pdf (дата звернення: 29.12.2019).

12. History of Cryptocurrency, Part I: From Bitcoin's Inception to the Crypto-Boom. URL: https://cointelegraph.com/news/history-ofcryptocurrency-from-bitcoins-inception-to-thecrypto-boom (дата звернення: 29.12.2019).

13. Електронний ресурс. URL: https:// coinmarketcap.com/ru/all/views/all/ (дата звернення: 29.12.2019).

14. Економічна теорія: Політекономія: Підручник / За ред. В.Д. Базилевича. - 7-ме вид., стер. - К.: Знання-Прес, 2008. - 719 с.

15. Выбираем карту (Visa, MasterCard), поддерживающую криптовалюты. URL: https://medium.com/@cryptospeaker/cryptocards-984ec8831f9d (дата звернення: 29.12.2019).

16. Лобачева, Е.Н., Родионова, В.Г. Инновации в системе электронных платежей / Гуманитарный вестник. - 2014. -№1(15). C. 16 .

17. Petya. URL: https://uk.wikipedia.org/ wiki/Petya (дата звернення: 29.12.2019). 
Банківське та фінансове право

\section{SUMMARY}

The article presents studies of the historical background, originand formation of cryptocurrencies. Special attention is paid to the study of inventors' and scientists' works that preceded and became the basis for the future creation of cryptocurrencies.

This article analyzes the main concepts and theoretical ideas that have become the basis and essential reason for the attempt to implement a new concept of the monetary system through a decentralized electronic monetary system. The system that could become an alternative to modern monetary systems and could respond to the challenges and needs of society, such as the speed and simplicity of crossborder financial transactions, decrease in the number (exclusion) of intermediaries, decentralization, $i$. e. the implementation of subjects equality in the field of money turnover.

An important aspect of the cryptocurrencies development is the possibility and prospect of their use as means of payment. Therefore, the above study analysed their main advantages and disadvantages as means of payment.

During this study, the main advantages of cryptocurrencies were highlighted: high speed of transfer; universality of processes (apart from the commission amount); relatively low fees; absence of intermediaries; anonymity of transactions; impossibility of transactions counterfeit or interference of third parties in the system.

At the same time cryptocurrencies, if there are significant advantages, have several disadvantages, such as: specific technicaldifficulties of use (additional equipment and software solutions are needed for the storage and usage of cryptocurrencies); unregulated legal status of cryptocurrencies, as a result, the presence of significant risks in the use of the object that exists outside the legal framework; relatively minor public awareness of cryptocurrencies; high volatility of cryptocurrencies, that is, a rapid change of cryptocurrencies value rates on the market; anonymity (at the same time is both an advantage and disadvantage, because it can be extremely difficult to return money in case of wrong transfer); high risk of fraudulent and illegal schemes with the cryptocurrencies turnover.

The analysis of the historical period of cryptocurrencies development and formation, as well as the prospects for use as means of payment makes it possible to conclude that soon enough cryptocurrencies can become an essential component of the global financial system.

Keywords: Cryptocurrency, electronic money, Bitcoin, Ripple, monetary system, means of payment. 